\title{
A cidade na sala de aula: estudo sobre os espaços de lazer com jovens do ensino médio
}

\author{
The city on the classroom: a study on leisure spaces with high \\ school young
}

\section{La ciudad en el aula: estudio sobre los espacios de ocio con jóvenes de la enseñanza media}

\author{
Flavia Cristina Coletti \\ https:/ / orcid.org/0000-0002-5487-1018 \\ flaviaccoletti@hotmail.com \\ Colégio Estadual Antônio Tupy Pinheiro - SEED/PR
}

Marquiana de Freitas Vilas Boas Gomes https:/ / orcid.org/0000-0002-4658-3569

marquiana@unicentro.br

Universidade Estadual do Centro-Oeste, UNICENTRO, Guarapuava, PR

Resumo: A relação entre cidade e educação é um meio para a formação da cidadania, e a geografia escolar pode contribuir neste processo. Discute-se neste artigo, através de pesquisa-ação realizada com jovens do ensino médio de uma escola pública na cidade de Guarapuava, como os jovens se apropriam de conhecimentos de geografia no cotidiano como forma de desenvolvimento do pensamento geográfico. Com espaços de lazer como tema, aplicou-se uma sequência didática de coleta de dados por meio de questionário, mapas mentais, pesquisa de campo e rodas de conversa. Foram verificados mecanismos, no conjunto de conteúdos, conceitos e procedimentos da geografia escolar, para a formação da cidadania no protagonismo do jovem no reconhecimento dos problemas e na construção de soluções para ler, interpretar e agir sobre a cidade.

Palavras-chave: lazer, ensino de geografia, cidade educadora.

Abstract: The relation between the city and education is a way for citizenship formation, and the scholar geography can help in this process. This paper discusses results of an action-research performed with high school young people in a public school in Guarapuava to verify how young people's daily knowledge can be appropriate for geography teaching as a way of geographic thought development. Leisure places were chosen as heme and it was applied one didactic sequence, which collected data using a questionnaire, mental maps, field research, and conversation circle. It was verified mechanisms in the set of contents, concepts, and procedures of school geography, for the formation of citizenship in young people, as the recognition of problems, the construction of solutions aiming to read, interpret and act on the city.

Keywords: leisure, geography teaching, educator city. 
Resumen: La relación entre ciudad y educación es un medio para la formación de la ciudadanía, y la geografía escolar puede contribuir en este proceso. Esto es lo que se pretende discutir en este artículo, al socializar una investigación-acción realizada con jóvenes de la enseñanza media de una escuela pública en la ciudad de Guarapuava. En esa investigación se buscó verificar cómo los conocimientos del cotidiano de los jóvenes pueden ser apropiados en la enseñanza de Geografía como forma de desarrollo del pensamiento geográfico. Para ello, se eligió como tema los espacios de ocio y se aplicó una secuencia didáctica, en la cual se recopilar datos por medio de cuestionario, mapas mentales, investigación de campo y ruedas de conversación. Se verificó que el protagonismo del joven en el reconocimiento de los problemas y en la construcción de soluciones, sumado al conjunto de contenidos, conceptos y procedimientos para leer, interpretar y actuar sobre la ciudad por la geografía escolar, es un mecanismo para la formación de la ciudadanía.

Palabras clave: ocio, enseñanza de geografía, ciudad educadora.

\section{INTRODUÇÃO}

A vivência na cidade, por si só, constitui um espaço de aprendizagem espontânea e permanente. A cidade nos fala muito por meio dos seus objetos e sua história, porém é necessário interpretá-la e observá-la para conseguir desvendar seus símbolos e participar de sua construção. Assim, pode-se dizer que todas as cidades educam, muito ou pouco, para o bem ou para o mal, não apenas nas instituições educativas, mas em sua totalidade, levando em consideração seu nível descritivo. Na perspectiva de uma "cidade educadora", significa que elas devem educar mais e melhor, ou seja, "sempre é possível e necessário otimizar a projeção educativa da cidade" através da relação entre cidade e educação (Bernet, 1997, p. 20).

Gadotti (2006, p. 134) porém, afirma "que na cidade que educa, todos os seus habitantes usufruem das mesmas oportunidades de formação, desenvolvimento pessoal e de entretenimento que ela oferece". Assim, toda a cidade pode ser considerada educativa, mas nem todas seriam educadoras.

Nessa relação, Bernet (1997) estabelece dimensões de aprendizagem na cidade ao mostrar que se pode: a) Aprender na cidade - quando esta é possuidora de educação, com instituições, relações, recursos e experiências educativas; b) Aprender da cidade - quando a mesma se apresenta como agente de educação informal, com modos de vida, atitudes, valores, tradições e costumes. Aqui, consideram-se as ruas da cidade enquanto uma 'escola da vida', um grande canal, repleto de significados, conteúdos dispersos, sem uma ordem ou hierarquia epistemológica específica; c) Aprender a cidade - considera-se a cidade enquanto conteúdo escolar, daí, o compreender seu desenho, sua forma e seu tamanho. Nesse caso, converte-se a própria cidade em conteúdo da educação, assim podemos 'aprender a cidade' se 'aprendermos da cidade'. Nesse sentido, a escola pode ser uma importante aliada para aprender $d a$ e $a$ cidade.

Carrano (2003) segue Bernet (1997) ao dizer que se pode aprender na cidade quando se examinam as instituições, os equipamentos e a circulação da cidade. Ainda, se aprendem 
da cidade os modos de vida, as atitudes, os valores, tradições e costumes e, com isso, nos tornarmos incluídos e usufruindo de seus recursos. Por fim, pode-se apreender a cidade no momento em que ela é compreendida.

Filmus (1997), por sua vez, esclarece que para aprender a cidade, além da importante articulação entre a cidade e a escola, é necessária ainda maior participação da comunidade local nos processos educativos, pois esse público traz consigo experiências e ricos conhecimentos, adquiridos em seu cotidiano. É importante proporcionar a essa comunidade um maior conhecimento da cidade, para que possam conhecer os processos sociais, analisá-los e compreendê-los, e enfim participar deles. Ou seja, o ambiente da cidade oferecido à população para ser explorado deve possuir espaços e equipamentos adequados ao desenvolvimento social, cultural e moral, com todos os seus habitantes tendo o direito de participar do planejamento do projeto educativo e na gestão da cidade.

Dentre os habitantes que vivem a cidade, estão os jovens, enquanto grupo social que possui interesses específicos, seja para sua sociabilidade, estudos ou trabalho. Por isso, a importância de investigações que compreendam a representação dos jovens sobre a cidade e como isso interfere na forma como constroem seu modo de agir e viver.

A escola pode participar desse entendimento de diferentes formas. Particularmente, por meio da geografia escolar, espera-se que os (as) estudantes compreendam a cidade, suas paisagens e territórios, na trama histórica, social, econômica, cultural e ambiental que os envolvem na produção desse espaço. Para isso, as relações espaciais cotidianas, inerentes a qualquer indivíduo, podem ser incorporadas ao ensino de Geografia. Mesmo se entende-se que o estudante já possua uma cultura geográfica do cotidiano, esse saber, contudo, não substitui o conhecimento escolar, tampouco há hierarquia ou equivalência entre eles. Segundo Vygotsky (2001), o saber espontâneo (adquirido no cotidiano) e o científico (próprio da escola) são necessários para o desenvolvimento humano e, enquanto o primeiro é construído a partir das práticas concretas, o segundo é sistematizado e adquirido na escola. Nessa, o estudante entra em contato com o conhecimento sistematizado induzindo sua percepção generalizante, a qual tem um papel importante no desenvolvimento do processo mental. Ainda para Vygotsky (2001), a formação de um conceito é um processo criativo não-passivo, que surge através de uma complexa operação orientada para resolver um problema, de modo que condições externas, simplesmente, como a relação entre as palavras e objetos, não bastam para produzir um pensamento conceitual. Para que ele ocorra é necessário então que surja um problema, que não possa ser resolvido de outra forma, a não ser pela formação de novos conceitos.

O sujeito é ativo no processo de formação do próprio conhecimento e seus saberes cotidianos integram esse processo. Cavalcanti (2005) esclarece que:

No nível de abstração e de generalização, o processo de formação de conceitos cotidianos é (...) impregnado de experiência, mas de uma forma ainda não-consciente (...) "ascendendo" para um conceito definido conscientemente; os conceitos científicos surgem de modo contrário, seu movimento é "descendente", começando com uma definição verbal com aplicações não espontâneas e, posteriormente podendo adquirir um nível de concretude impregnando-se na experiência (Cavalcanti, 2005 p.197). 
Os estudantes, segundo a autora, constroem de maneira inconsciente um saber geográfico ao se relacionarem com a cidade e seus lugares, de modo que para desenvolverem o pensamento geográfico é preciso que compreendam os conceitos, localizem-nos e deem significados aos lugares e as suas experiências cotidianas. E, nisso, o papel do professor é fundamental ao iniciar o processo de buscar conhecer o jovem e valorizar sua experiência e diversidade - cada jovem possui uma geografia própria que envolve um conhecimento espacial. Ao considerar os propósitos do ensino, é possível desenvolver o saber espacial empírico do estudante em conhecimento geográfico consciente, o que implica, além dos conceitos próprios desta área, a formação para a cidadania.

Nesse sentido, na escola a geografia escolar, ao considerar a cidade como o conteúdo, pode desenvolver no jovem um laço de maior afetividade e solidariedade, por meio do desenvolvimento de relações de pertencimento ao espaço vivido, valorizando e problematizando suas experiências (Brarda \& Ríos, 2004).

Assim, esse artigo relata os resultados de uma pesquisa realizada com jovens do ensino médio de uma escola pública de Guarapuava, sobre como os conhecimentos do cotidiano dos jovens na cidade podem ser apropriados no ensino de Geografia como forma de desenvolvimento do pensamento geográfico sobre o espaço urbano. Para isso, elegeu-se como tema o lazer, espaço-tempo que tem centralidade na vida dos jovens devido ao seu papel na sociabilidade juvenil.

O texto está dividido em três partes. Na primeira, apresentam-se os materiais e métodos utilizados. Na segunda, a caracterização dos jovens do ensino médio participantes da pesquisa e, na terceira e última parte, o detalhamento da realização de uma sequência didática (SD) sobre o lazer na cidade de Guarapuava.

\section{MATERIAIS E MÉTODOS}

O texto resulta de uma pesquisa-ação ${ }^{1}$ sobre as condições dos espaços de lazer na cidade de Guarapuava com 27 estudantes do ensino médio do Colégio Estadual Antônio Tupy Pinheiro, e professores da educação básica e da Universidade Estadual do CentroOeste (UNICENTRO).

Tendo como base as orientações de Thiollent (2004), foram considerados três aspectos interdependentes: a resolução de problemas coletivamente identificados - neste caso, as condições dos espaços de lazer na cidade de Guarapuava; a tomada de consciência, ou seja, a importância dessas áreas para a sociabilidade juvenil, aspectos positivos e negativos da sua distribuição na cidade (bem como suas condições de infraestrutura) e a produção de

1 Todas as ações e a pesquisa fazem parte do projeto de extensão, denominado "Guarapuava Educadora: Juventude educando-se na/com a Cidade", e do projeto de pesquisa: "Educar-se com/na cidade de Guarapuava-PR: práticas socioespaciais da juventude escolar". O primeiro financiado pela Secretaria de Ciência, Tecnologia e Ensino Superior, por meio do Programa Universidade Sem Fronteiras, e o segundo, pela Fundação Araucária. Deles, resultaram, dentre outras produções, a dissertação de mestrado intitulada: A Cidade e seu potencial educativo: a relação entre o cotidiano e o conhecimento científico no ensino de Geografia, na qual se coletaram os dados apresentados neste artigo. 
conhecimento - realizada a pesquisa, buscou-se elaborar sugestões para os problemas identificados com o intuito de se construir uma pauta apresentada ao poder público municipal.

Por meio de uma Sequência Didática, elaborada no âmbito de um projeto de extensão universitária, realizaram-se ações em três fases:

A) Fase 1 - Diagnóstico e Problematização, realizada por meio de aplicação de questionário aos jovens estudantes participantes, com ênfase nos aspectos social, econômico, lazer, família, cotidiano, escola e carreira. Os dados obtidos foram sistematizados e apresentados aos estudantes como problematização do tema da sequência didática - Lazer em roda de conversa. Nessa, os estudantes tiveram espaço para refletir sobre os dados e falar sobre os assuntos de forma livre. Toda a sessão foi gravada em vídeo para análise posterior. Outra ação foi a produção de mapas mentais pelos estudantes com o tema Locais de lazer em Guarapuava. Esses mapas também foram analisados para a pesquisa para verificar os locais mais frequentados;

B) Fase 2 - Atividades pedagógicas - consistiu na elaboração e aplicação de uma pesquisa pelos próprios jovens estudantes sobre as áreas verdes na cidade, e envolveu análise de mapas e textos, entrevistas com moradores e pesquisa de campo. Essas ações ocorreram em 12 encontros de 50 minutos, sendo que um deles consistiu em um trabalho de campo de três horas;

C) Fase 3 - A terceira e última fase foi a socialização e avaliação dos resultados por meio de um seminário denominado Seminário de Socialização dos Trabalhos do Projeto Guarapuava Educadora: Jovens pensando a Cidade. Participaram desta atividade os jovens estudantes participantes da pesquisa, os estudantes de outras escolas (também integrantes do projeto de extensão não tratado neste texto), professores e direção do Colégio Estadual Antônio Tupy Pinheiro, professores da UNICENTRO, membros do Núcleo Regional de Educação e representantes do Poder Público Municipal das secretarias do Meio Ambiente, Esporte, Turismo e Cultura.

Tendo como referência a perspectiva da cidade educadora, optou-se por dar ênfase à dimensão do aprender da e a cidade, com ênfase no papel da escola como articuladora desse conhecimento. Para isso, todo o processo consistiu em criar possibilidades para que os jovens observassem a disponibilidade, localização e qualidade dos espaços de lazer públicos e privados na cidade. Os conceitos geográficos principais para abordagem do tema foram Lugar e Paisagem.

O registro das ações ocorreu por meio de fotos, filmagens e diários de campo. Os 27 participantes, 16 meninas e 11 meninos, foram identificados em seus depoimentos por F e M, respectivamente, seguidos por um número sequencial arábico ${ }^{2}$.

2 Essa pesquisa foi aprovada no Comitê de Ética em Pesquisa (COMEP) da UNICENTRO, sob o Certificado de Apresentação de Apreciação Ética (CAAE) número 97592818.3.0000.0106 parecer número 2.941.745. 


\section{ANÁLISE E DISCUSSÃO DOS RESULTADOS}

\section{Jovens participantes da pesquisa: a condição juvenil e seu contexto de vivência}

Dayrell (2005) afirma que há um conjunto de representações sociais sobre a juventude que influencia nossa maneira de ver os jovens. Não raro, a juventude é vista enquanto "uma condição de transitoriedade" e o jovem é um "vir a ser", e com ela uma tendência a sua negatividade:

Essa concepção está muito presente na escola: em nome do "vir a ser" do aluno, traduzido no diploma e nos possíveis projetos de futuro, tende-se a negar o presente vivido do jovem como espaço válido de formação, assim como as questões existenciais que eles expõem, bem mais amplas do que apenas o futuro (Dayrell, 2005, p. 40).

Outra representação seria a da juventude como um tempo de liberdade. Nesse caso, haveria um tipo de moratória social, um tempo para o ensaio e o erro, para experimentações, e com ela uma relativização da aplicação de sanções sobre o comportamento juvenil. E, além dessas, a representação do jovem reduzido ao campo da cultura. Imagens que convivem com a ideia de juventude como momento de crise, fase difícil e de conflitos (Dayrell, 2005).

Turra Neto (2008), Carrano (2011) e Cassab, Mendes e Nazareno (2011), em consonância com as ideias de Dayrell (2005), argumentam a importância de ver a juventude na sua pluralidade, nas implicações que a renda, raça e gênero têm na vida do jovem e na sua condição de vivenciar a juventude. Argumentam ainda que viver a juventude, em relação aos jovens das classes populares, além das representações sociais já imbricadas na sua condição juvenil, está condicionada a um conjunto de fatores onde pesam as desigualdades aos quais estão submetidos.

Essas considerações foram a base para a construção das atividades com os jovens participantes da pesquisa, pois entende-se que para uma geografia escolar inclusiva voltada para a cidadania é importante entender a juventude no plural, o contexto de vida dos estudantes, sua cidade, a escola e as condições familiares. Para o nosso recorte de estudo, significa considerar as condições econômicas e culturais da cidade de Guarapuava, as condições de infraestrutura do Colégio Estadual Antônio Tupy Pinheiro e informações sobre renda e educação das famílias dos jovens participantes.

Guarapuava se caracteriza como uma cidade de porte médio localizada na região Centro-Sul do Estado do Paraná, com uma população urbana de 152.993 habitantes, o que corresponde a cerca de $92 \%$ da população total do município, de 167.328 (Instituto Brasileiro de Geografia e Estatística [IBGE], 2010).

Nos últimos 40 anos, concomitante ao processo de urbanização, ocorreu uma transformação em vários outros setores da vida urbana, inclusive nos hábitos de consumo da população, o que demandou a ampliação e melhoria na qualidade dos serviços públicos. Atualmente, apresenta o índice de desenvolvimento humano (IDH-M) de 0,731, considerado alto, conforme os dados do Programa das Nações Unidas para o Desenvolvimento (PNUD, 2010) e do Instituto Paranaense de desenvolvimento Econômico e Social (IPARDES, 
2010). Este dado deva ser olhado com cuidado, pois a concentração de renda é elevada ${ }^{3}$ no município (Brasil, 2010) e, nos últimos 20 anos, o incremento em infraestrutura, equipamentos e empreendimentos urbanos seriam os responsáveis pela melhoria dos índices relacionados às condições de vida da população (Tab. 1).

Tabela 1. Evolução das condições de vida da população de Guarapuava, PR.

\begin{tabular}{l|l|l|l}
\hline Variáveis & $\mathbf{1 9 9 1}$ & $\mathbf{2 0 0 0}$ & $\mathbf{2 0 1 0}$ \\
\hline Índice de Desenvolvimento Humano (IDH) & 0,473 & 0,632 & 0,731 \\
\hline Esperança de Vida ao nascer / anos & 68,48 & 73,94 & 76,20 \\
\hline Longevidade (IDHM-L) & 0,725 & 0,816 & 0,853 \\
\hline Educação (IDHM) & 0,223 & 0,450 & 0,628 \\
\hline Renda (IDHM) & 0,626 & 0,689 & 0,730 \\
\hline vulneráveis a pobreza (\%) & 64,40 & 49,12 & 27,71 \\
\hline domićlios com água encanada (\%) & 74,41 & 92,17 & 98,55 \\
\hline domić́lios com energia elétrica (\%) & 82,07 & 96,40 & 99,01 \\
\hline
\end{tabular}

Fonte: IPARDES, 1991, 2000, 2010 e 2018. IBGE, 1991, 2000, e 2010.

Nessa conjuntura, de transformação social, também o espaço urbano se modifica. Resta saber se essas mudanças conseguem promover equidade e justiça social. São muitos os aspectos necessários para responder a essa questão, nesse texto nosso foco será a condição dos espaços de lazer, tema da sequência didática desenvolvida com os jovens.

O Colégio Estadual Antônio Tupy Pinheiro localiza-se próximo à área central da cidade de Guarapuava. Possui 935 estudantes matriculados em três turnos, oriundos de diversos bairros da cidade e de diferentes classes sociais. O colégio tem uma infraestrutura bem conservada, com salas de aula bem cuidadas, bibliotecas, anfiteatro para 100 pessoas e uma quadra poliesportiva. O Índice de Desenvolvimento da Educação Básica (IDEB) de 2017 foi de 4,5, sendo que a meta do Brasil para o IDEB de 2017, de 4.7, não foi atingida por nenhum estado brasileiro (SEED, 20194).

Os jovens estudantes participantes da pesquisa estudam no período matutino, todos solteiros e sem filhos, sendo $59 \%$ de jovens meninas e $41 \%$ de jovens meninos. A distribuição da faixa etária está entre 14 e 18 anos, conforme a Figura 1.

3 O Índice ou Coeficiente de Gini é uma medida de desigualdade de dados que é utilizada para medir a desigualdade de renda, quanto mais próximo de 1 pior é o índice, quanto mais próximo de 0 , é melhor. No ano de 2000 o índice do município de Guarapuava foi de 0,6224 e, em 2010, foi para 0,5452, indicando melhora, mas inda é insuficiente. Em comparação, o Paraná na mesma data tinha um índice de 0,5416. O que não destoa da realidade brasileira, cujo índice é de 0,6086 e a região sul, 0,537, Fonte: Brasil, Ministério da Saúde. Recuperado de http://tabnet.datasus.gov.br/cgi/ibge/censo/cnv/giniuf.def

4 Consulte http://www.consultaescolas.pr.gov.br/consultaescolas-java/pages/templates/initial2.jsf;jsessionid=kOUq9_ CaGP2oHG_XL0OvSI5WYkEQh1YoiwQ3VfP7.sseed75003? windowId=50e\&codigoNre=\&codigoMunicipio=950. 
Figura 1. Distribuição de faixa etária

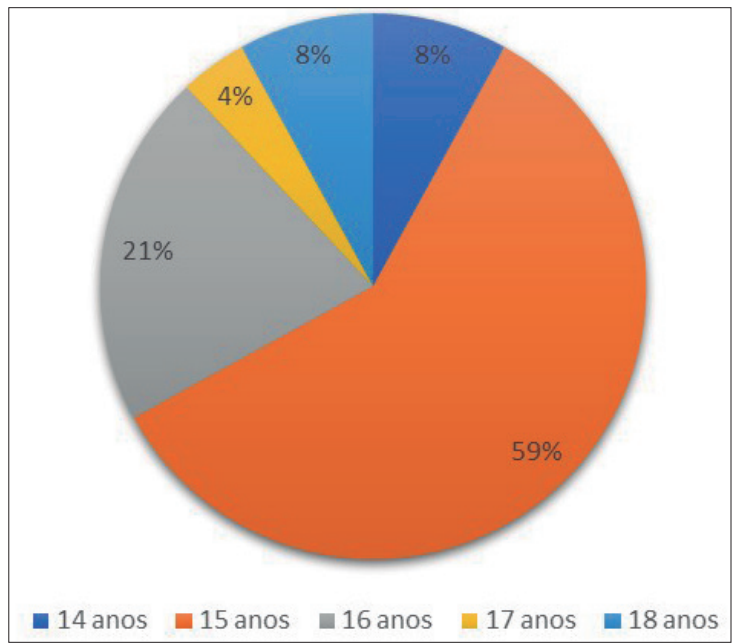

Eles residem em diferentes bairros da cidade: Vila Bela, Cascavel, Boqueirão, Jardim das Américas, Jardim dos Estados, Conradinho e Industrial, nos quais predominam a baixa renda. A maior parte, $76 \%$, são nascidos em Guarapuava, enquanto $16 \%$ vieram de municípios vizinhos e $8 \%$ de dois outros estados. Em relação à composição familiar, $67 \%$ moram com pai e mãe, enquanto $26 \%$ só com a mãe, ou com os avós $(7 \%)$. Em relação à moradia $74 \%$ possui casa própria, $22 \%$ alugada e $4 \%$ cedida.

Grande parte das famílias dos jovens é de baixa renda, como podemos verificar na Figura 2, que demostra que muitas delas ganham abaixo de um salário mínimo5. Destas, $85 \%$ dos responsáveis trabalham, $11 \%$ não responderam e $4 \%$ não trabalham. As profissões dos responsáveis exigem baixa qualificação e escolaridade, predominando a prestação de serviços como carteiro, soldador, serviços gerais, mecânico, mestre de obras, etc. Sobre a escolaridade dos responsáveis, $11 \%$ possui ensino superior e $11 \%$ tem o ensino fundamental e médio completos, os demais (88\%) não tem ensino fundamental completo. Portanto, muitos dos jovens já têm escolaridade superior aos de seus pais e veem a escola como uma porta para a mobilidade social.

Figura 2. Distribuição de renda

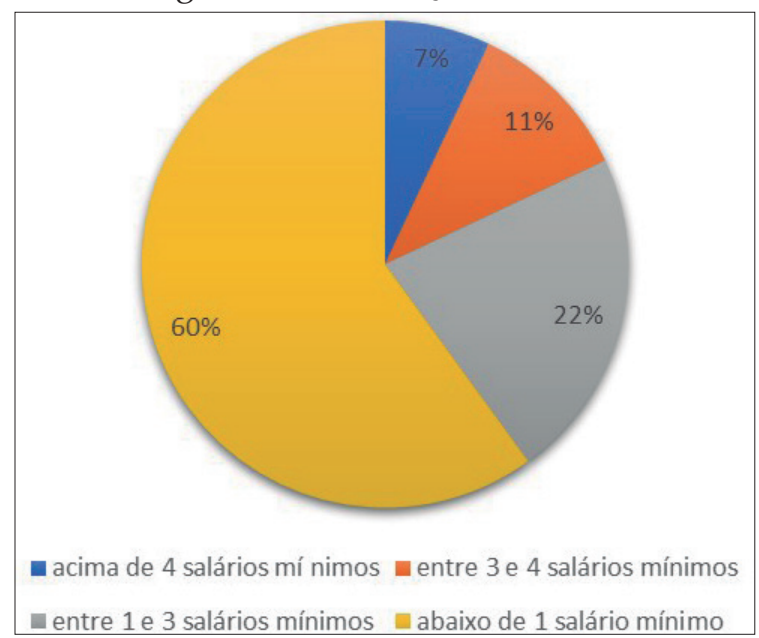

5 O salário mínimo considerado foi de $\mathrm{R} \$ 998,00$. 
Com vistas a detalhar os diferentes passos da SD, na sequência buscar-se-á apresentar as fases da pesquisa - Diagnóstico e Problematização; Atividades Pedagógicas; e a Socialização e Avaliação dos Resultados.

\section{Sequência Didática - Espaços de Lazer na cidade de Guarapuava}

\section{Fase 1 - Diagnóstico e Problematização}

O diagnóstico foi a primeira atividade realizada com os jovens, por meio da aplicação de um questionário e, por meio de sua sistematização, realizou-se a problematização coletiva. Iniciou-se essa última com os jovens estudantes por meio da apresentação dos dados, referentes às suas atividades de lazer, indicadas no diagnóstico (Figs. 3 e 4) e da exposição de imagens do Parque do Lago (Fig. 5) e do Shopping Cidade dos Lagos (Fig. 6). Por meio dessas figuras estabeleceu-se um debate sobre as preferências e limites no exercício do lazer na cidade de Guarapuava.

Sobre as preferências dos jovens, a permanência em casa (Fig. 3) para navegação na internet é a principal atividade de lazer realizada (78\%), embora, por gênero (Fig. 4) essa proporção seja maior para jovens meninas (56\%) do que para jovens meninos (22\%). Ao analisar os dados, afirmaram que a cidade é mais perigosa para as jovens meninas devido ao assédio sexual, motivo pelo qual elas ficam mais em casa que eles. Embora um deles tenha ponderado que "para os meninos também é perigoso, pois tem assaltos e brigas" (aluno M6).

Figura 3. Principais atividades de lazer dos jovens na cidade de Guarapuava, PR.

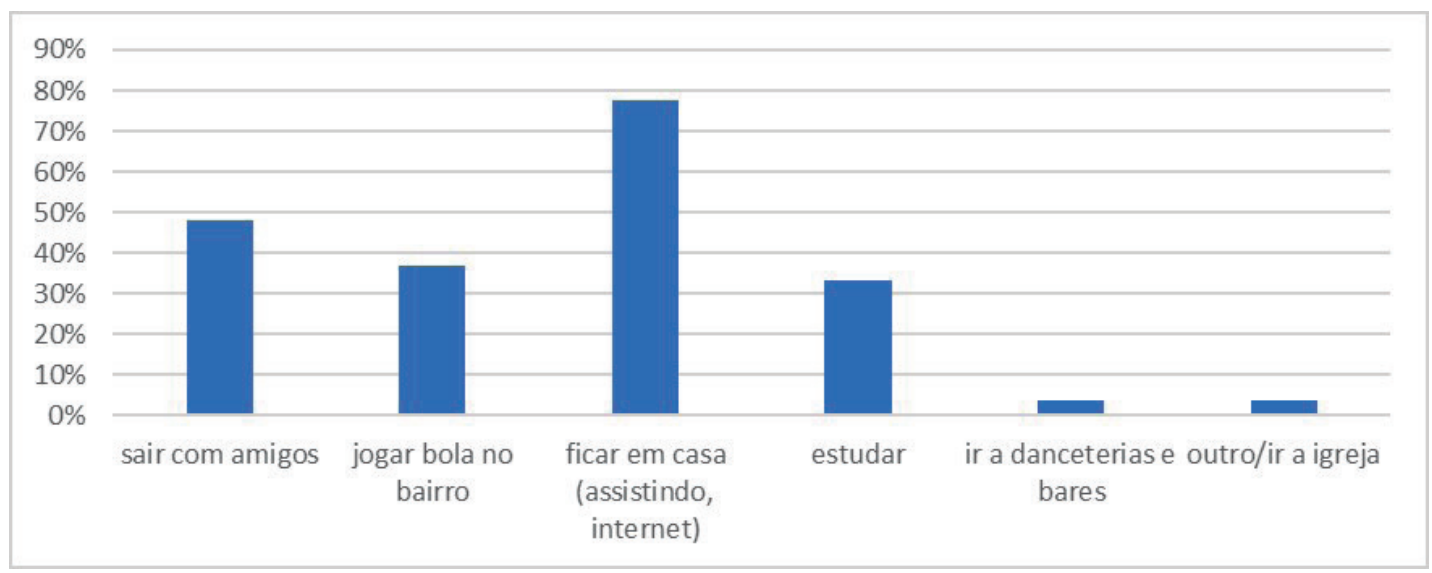

A internet, sua principal fonte de informação, é usada por $96 \%$ dos jovens e, segundo eles, as redes sociais são o meio de comunicação principal para conversar com os amigos. Os assuntos tratados são os mais variados, com destaque para a conversa sobre música (70\%), combinar rolês6 (67\%), falar sobre relacionamentos (67\%), estudos (59\%), esportes $(56 \%)$, filmes (48\%) e jogos (41\%). Ao comentarem esses dados, também afirmaram que conversam sobre religião, conflitos familiares, planos para o futuro, política, drogas e sexo.

6 Rolê é o termo usado pelos jovens para designar um passeio sem preocupação nem compromisso. 
Figura 4. Principais atividades de lazer dos jovens conforme gênero na cidade de Guarapuava, PR.

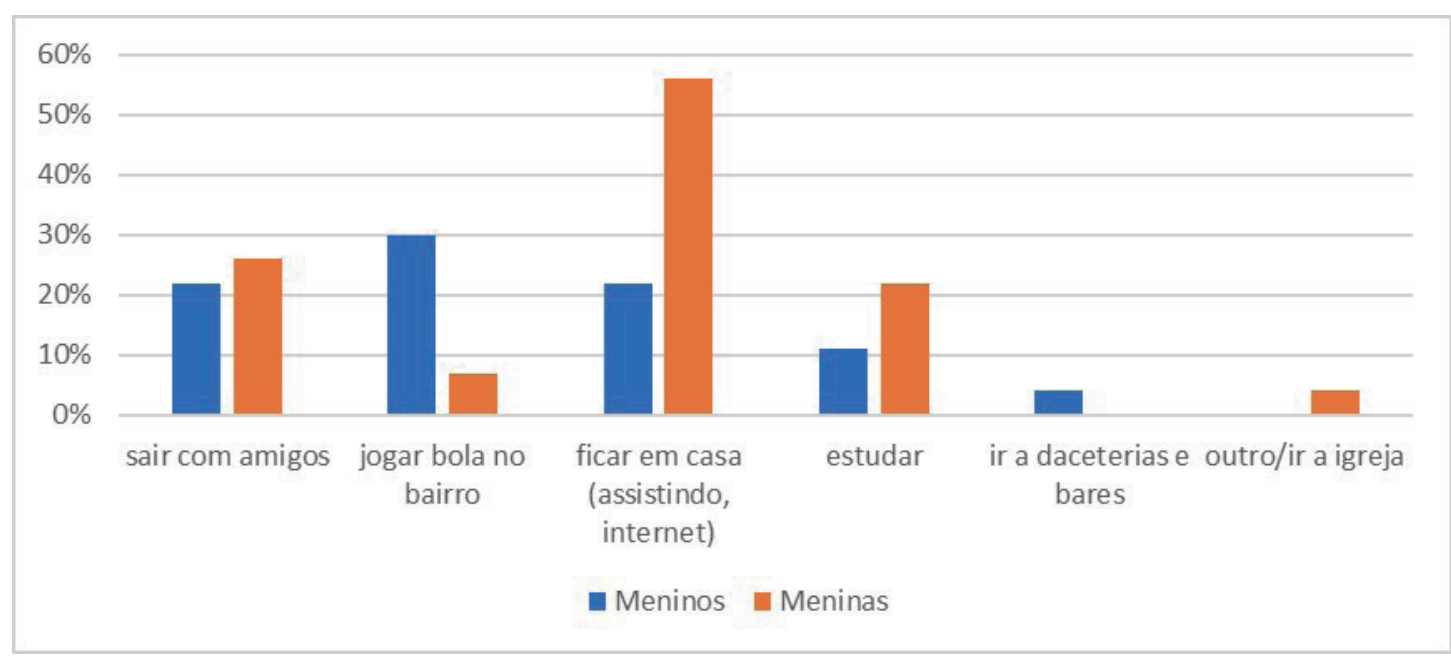

Constatou-se que os meios de comunicação exercem papel fundamental na representação da (in) segurança na cidade, dos jovens e seus familiares. Todos os dias eles são bombardeados com notícias sobre a violência nos grandes centros urbanos, e esse efeito tornou-se ainda maior com a democratização das informações nas redes sociais, fato que criou uma falsa equivalência entre os acontecimentos nas diversas partes do Brasil e do Mundo àqueles na sua cidade. Isso, mesmo que essa percepção possa ser refutada por meio da comparação entre os grandes centros e Guarapuava, principalmente quanto a proporção e a natureza da violência. Como parâmetro, comparando Guarapuava com a capital do estado Curitiba, com quase dois milhões de habitantes (IBGE, 2010), de acordo com o Relatório Estatístico Criminal da Secretaria de Segurança Pública e Administração Penitenciária do Estado do Paraná, em 2018 foram consumados 25.291 roubos na capital e apenas 692 em Guarapuava. Esse é um exemplo de como a sensação de insegurança é maior que os fatos concretos, ocorridos na cidade. A sensação de insegurança é ainda ampliada com a democratização da informação pela internet pois recebe-se informação instantânea sobre diferentes lugares e situações. À essa representação, soma-se o desejo de proteção dos familiares e as questões culturais que restringem a liberdade com base em valores culturais, sobretudo às jovens meninas.

A ausência de opções para lazer também é a justificativa dada por eles pela opção de permanecer em casa, ainda que sair com os amigos também seja uma atividade importante, citada por $48 \%$ deles. Entre os locais de lazer que mais frequentam estão os Parques e Praças (citados por 61\% deles, com destaque para o Parque do Lago, mencionado por $39 \%)$, seguido de lanchonetes e bares (39\%), sorveterias (22\%) e andar pela Rua XV de Novembro (13\%). 
Figura 5. Parque do Lago, Guarapuava, PR.

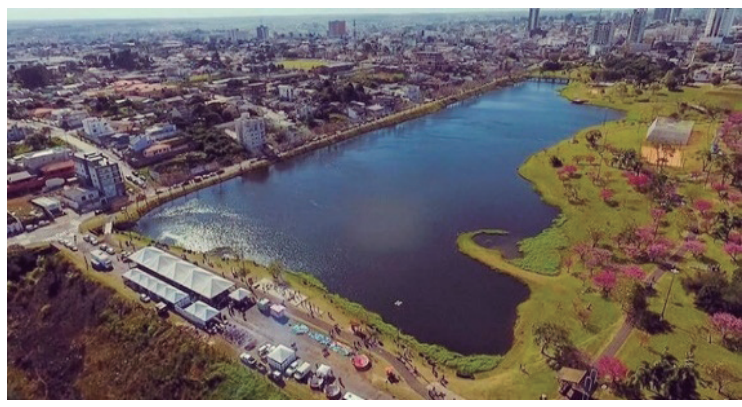

Fonte: Jornal Extra Guarapuava, 2018.
Figura 6. Shopping Cidade dos Lagos,

Guarapuava, PR.

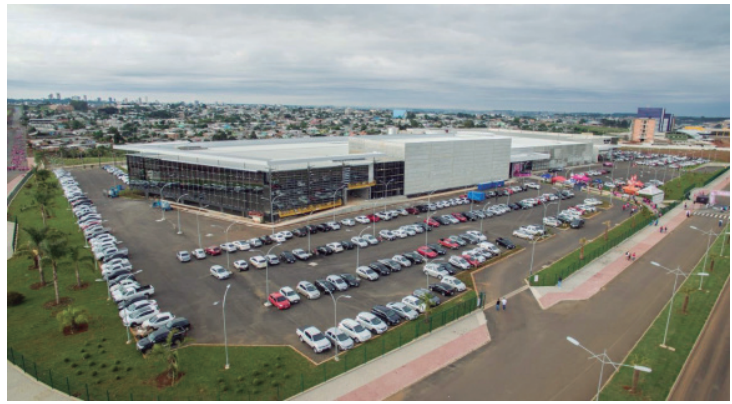

Fonte: http://www.

Shoppingcidadedoslagos.com.br/

Os parques e praças atraem os jovens por ser um espaço público e gratuito, enquanto que as lanchonetes e sorveterias, mesmo sendo muito citado, exige o consumo, não sempre possível pela condição financeira do jovem.

Sobre a centralidade da Rua XV em relação às demais ruas da cidade, Turra Neto (2008) já havia indicado essa preferência dos jovens, em diferentes gerações da cidade. Na pesquisa realizada pelo autor, ele identificou que, mesmo com o crescimento da cidade, a rua central ainda concentra vários estabelecimentos comerciais, como lanchonetes, sorveterias, lojas de departamento entre outros.

Outra atividade de preferência diz respeito a jogar bola entre amigos, predominantemente no próprio bairro (37\%) e praticado por jovens meninos; apenas duas jovens meninas afirmaram jogar bola. Além de ser uma atividade coletiva, também é gratuita e pode ser realizada na rua, em terrenos baldios ou em eventual campo de futebol no bairro.

Os jovens também indicaram que estudar é uma forma de lazer (citado por 33\% deles), sendo a escola um espaço de sociabilidade importante, pois é também um lugar de encontrar amigos e se relacionar.

Além dessas atividades mais citadas, estão também as danceterias (segundo eles, mais difícil de frequentar pela limitação de idade e pela necessidade de autorização dos responsáveis). A igreja é lembrada como um espaço de sociabilidade, principalmente para aqueles que participam de grupos de jovens ou outras atividades juvenis com periodicidade.

Para além da identificação dos locais frequentados e preferência dos jovens, a discussão com eles também permitiu verificar os impedimentos para o exercício do lazer (indicados por $63 \%$ deles). Entre os motivos mais citados têm-se a restrição imposta pelos responsáveis (37\%), a violência (33\%), às questões financeiras $(8 \%)$ e a mobilidade $(8 \%)$. Enquanto 37\% indicou que nada os impede, mais uma vez esta proporção é alterada se os mesmos dados são observados na perspectiva de gênero (Fig. 7). 
Figura 7. Motivos para restrição ao exercício do Lazer dos jovens na cidade conforme o gênero.

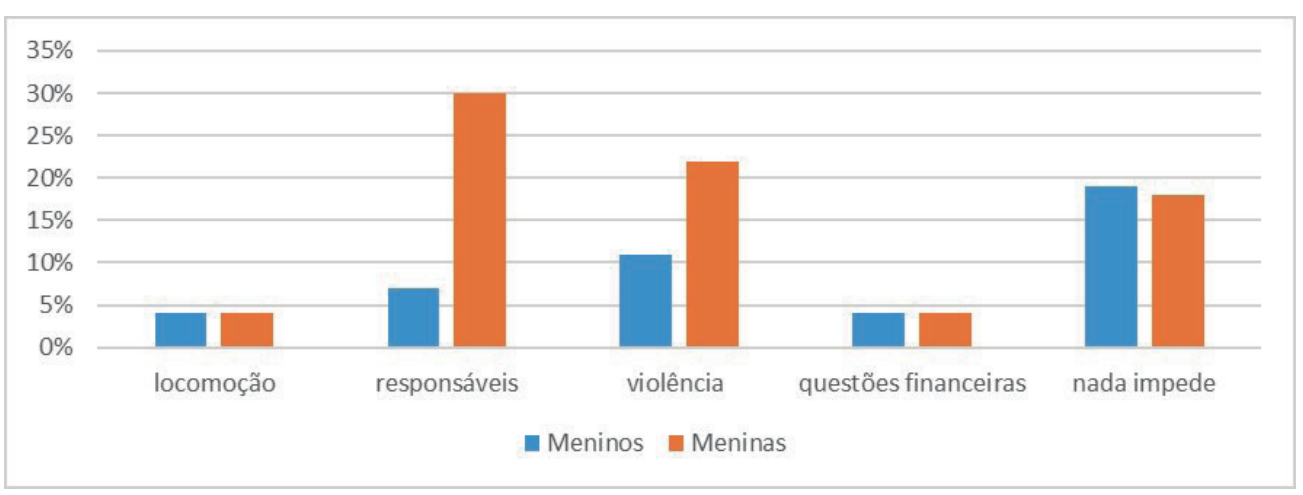

Fonte: Banco de dados do Grupo de Pesquisa EDUCARTGEO, 2019.

Como já mencionado, a espetacularização veiculada pela mídia, somada à experiência vivida por alguns deles ou de seus conhecidos, intensificam o medo de circularem pela cidade e a restrição pelos responsáveis. Por um lado, estão os roubos dos celulares, dinheiro, boné e, até mesmo, a agressão recebida do assaltante. Por outro, está a desconfiança em relação a polícia. Sobre isso, percebeu-se uma ambivalência quanto à representação que possuem sobre os policiais. Conforme o jovem M8: "Dependendo do lugar que eu esteja, eu posso me sentir tanto seguro ou até com medo. Porque, por exemplo, se eu estou andando em um bairro e a polícia passa, é obvio, sei lá, eles podem me parar, e já aconteceu isso. Mas se eu estou no lago, uma vez tentaram me assaltar no lago, não conseguiram, e passou a viatura depois. Eu estava com meu primo, a gente recorreu à viatura para ir atrás dos caras que tentaram nos assaltar. Então depende do local".

A abordagem por policiais não é algo estranho a eles, e o motivo geralmente é associado à sua aparência ou por andarem em grupos. Reportam que percebem tratamento diferenciado conforme o local pelo qual estão circulando, o que indica um código de conduta comportamental dos jovens, que é esperado pelos policiais, e que não sendo respeitado os coloca em risco de abordagem ou determinado tipo de tratamento. Isso serve para agentes de segurança público ou privada. Como relata outra jovem F19: "Esses dias estava tendo não sei o quê aqui na escola e daí a gente foi comprar algo para almoçar aqui. Chegamos lá no mercado e daí estava um monte de gente. Daí eles (os seguranças do supermercado) olhavam para nós e começaram a nos seguir, sabe?! Os seguranças começaram a falar, pensando que nós éramos bandidos, sabe?! Nós andávamos e eles andavam atrás dos piás". Complementando esse relato, outro aluno acrescentou: "Entrou oito adolescentes junto no mercado. Vai querer o quê? Claro que eles vão seguir" (aluno M8). Há neste caso, certa naturalização do estigma que carregam e os relatos indicam que não há surpresa para eles quanto a essa situação e, embora reconheçam que haja preconceitos, não se sentem seguros em questionar o tratamento que recebem. Diante disso, a forma que encontram para evitar os constrangimentos é reduzindo a sua mobilidade em certos locais e horários. Evitam andar em grupos e quando arriscam fazê-lo, buscam não confrontar policiais ou seguranças privados. A representação do jovem adolescente como risco, a imaturidade e a necessidade de controle pela família e pelo Estado também é frequentemente reforçada pela mídia e tem um efeito direto na vida 
e na limitação do jovem quanto à apropriação do espaço urbano (Menandro, Trindade, \& Almeida, 2003).

Sobre as restrições financeiras, aqueles que disseram não a considerarem tão importante explicaram que, na maioria das vezes, realizam atividades que não necessitam de dinheiro, tais como jogar bola no bairro, assistir TV, navegar na internet e/ou sair com os amigos. Contudo, observa-se que entre os que trabalham (15\% deles) há maior autonomia para desenvolver atividades de lazer, o que corrobora as observações de Turra Neto (2008) quanto à relação entre a condição financeira e a ampliação das possibilidades aos jovens das classes populares.

Em relação ao consumo, a inauguração do Shopping Cidade dos Lagos em 2018 foi esperada ansiosamente, e embora já conste no mapa mental de alguns deles entre os principais espaços de lazer (Fig. 8), afirmam que não conseguem frequentá-lo periodicamente devido ao constrangimento e a distância7. Muito jovens afirmaram não se sentirem bem no ambiente do Shopping, sobretudo, por não se perceberem como parte do mesmo. Tal fato se assemelha às constatações de Cassab, Mendes e Nazareno (2011) quanto à distinção territorial na circulação dos jovens nas cidades, decorrente do processo de desigualdade social. O que também se aplica a esse grupo de jovens em Guarapuava. Pelo que se ouviu nos depoimentos sua diferença social é um condicionante quanto aos espaços pelos quais circulam.

Figura 8 - Espaços de Lazer frequentados na cidade por um dos jovens.

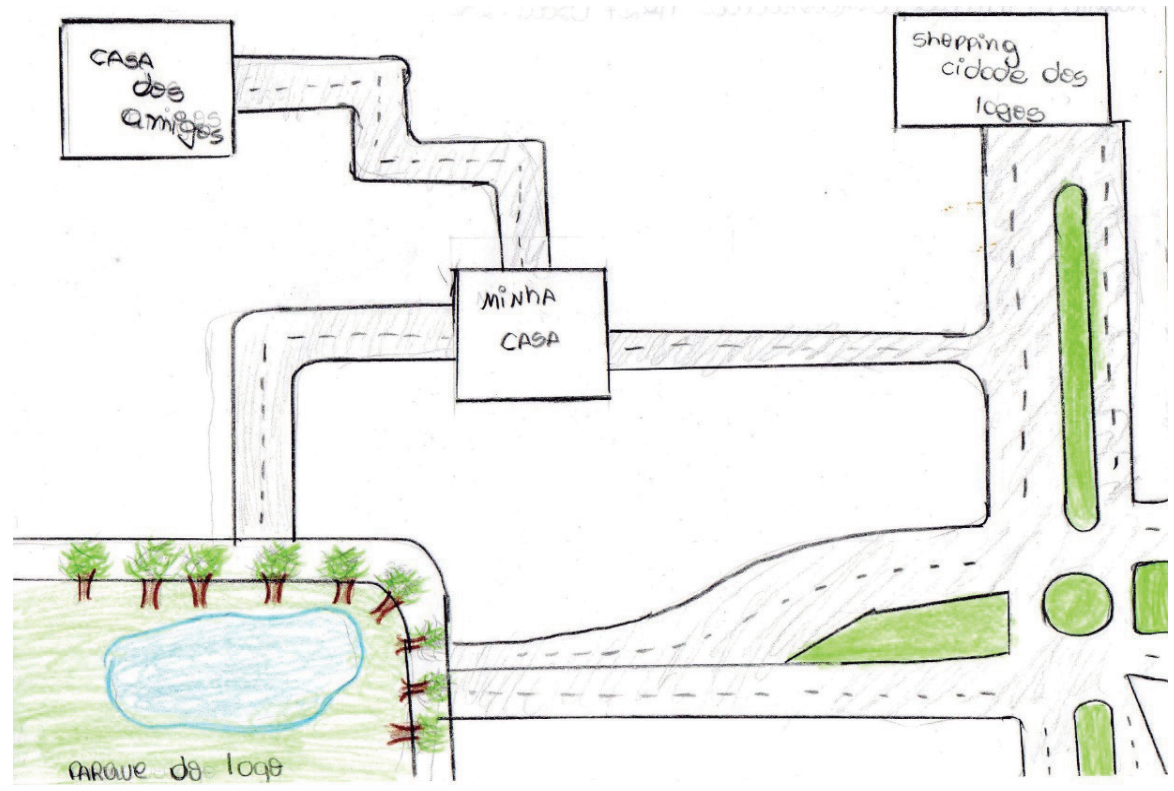

Fonte: oficina de mapas mentais, 2018.

O Shopping Cidade dos Lagos situa-se na zona norte da cidade, a 7,5 km do centro, ao lado de alguns bairros de baixa renda. A sua distância, em relação aos bairros de origem dos jovens participantes da pesquisa, não seria um problema (pois varia de 6 a $10 \mathrm{~km}$ ) se na cidade houvesse um sistema de transporte mais eficiente (em quantidade, qualidade e preço). 
Segundo M10, "Dependendo de onde mora, a pessoa precisa pegar até três ônibus pra chegar no Shopping, daí leva muito tempo, é cansativo". Outro fator é o poder de consumo de suas famílias que, segundo eles, é incompatível com os produtos e serviços oferecidos no Shopping. Outra menção diz respeito ao público que circula no estabelecimento, cuja distinção social é motivo para refutarem o espaço para o lazer.

Para os jovens, são vários os desafios para vivenciarem sua condição juvenil na cidade. Sobre isso, é importante frisar que o jovem pode ter idade biológica compatível às práticas de juventude, contudo, questões financeiras, religiosas, familiares, etc, podem ser restritivas desta condição e possibilidade que, segundo Turra Neto (2008), pode ainda ser potencializada ou reduzida conforme o que a cidade oferece. De qualquer modo, mesmo com as dificuldades financeiras e/ou de transporte, para os jovens participantes o lazer está entre as atividades que consideram mais prazerosas, pois nele potencializa-se sua rede de sociabilidade. Por isso, a cidade precisa disponibilizar espaços apropriados e com qualidade para que possam usufruir e viver sua juventude. Na sequência abordam-se as possibilidades em Guarapuava.

\section{Fase 2 - Atividades pedagógicas}

As atividades de pesquisa integraram a análise de mapas, entrevistas com moradores na cidade e pesquisa de campo, como será observado na sequência do texto.

\section{A) Análise do mapa dos equipamentos públicos de lazer na cidade}

A atividade iniciou com a observação do mapa da cidade e a localização dos espaços públicos de lazer. Nela, os jovens perceberam que a maioria possui algum tipo de equipamento público ou privado de lazer próximo à residência, seja praça, parque e/ou ginásio. Contudo, verificaram ainda que a concentração deles é maior na área central da cidade ou próxima a ela. Como observa a jovem F20: "Até tem parques e praças para se divertir em toda a cidade, mas no centro, ou perto do centro, têm mais, e lá são mais bonitas e conservadas. Nos bairros eles demoram para arrumar o que estraga e a população detona muito".

Observou-se, pelo comentário, que o fator estético também é atrativo ou motivo de repulsa pela população, assim como os casos de depredação dos equipamentos públicos. Há uma combinação de fatores que levam a isso, como a deficiência de políticas públicas de conservação, assim como o descuido dos próprios usuários.

Aproveitou-se para problematizar com os jovens o fato dos espaços públicos serem uma forma de controle social e o resultado das políticas públicas para consumo e valorização do solo urbano, principalmente nas cidades médias. Esses grandes empreendimentos, como parques, expressam valores éticos e estéticos que são usados para justificar as transformações feitas em determinados locais e que valorizam as áreas ao entorno (Serpa, 2007). Em Guarapuava, as praças e parques com melhor infraestrutura têm esse efeito sobre o entorno, como exemplificado pelo Parque das Araucárias (Fig. 9). Localizado no Bairro Primavera, na zona Norte da cidade, apresenta uma diversidade de usos, funções e formas voltadas para o lazer, onde as escolas podem fazer visitação guiadas por todo o percurso. É uma reserva de Mata com Araucárias que oferece à população acesso a trilhas 
ecológicas, visitação ao Museu de Ciências Naturais, ao viveiro de mudas e plantas medicinais, e atividades de Educação Ambiental.

Figura 9. Parque das Araucárias, Guarapuava, PR.

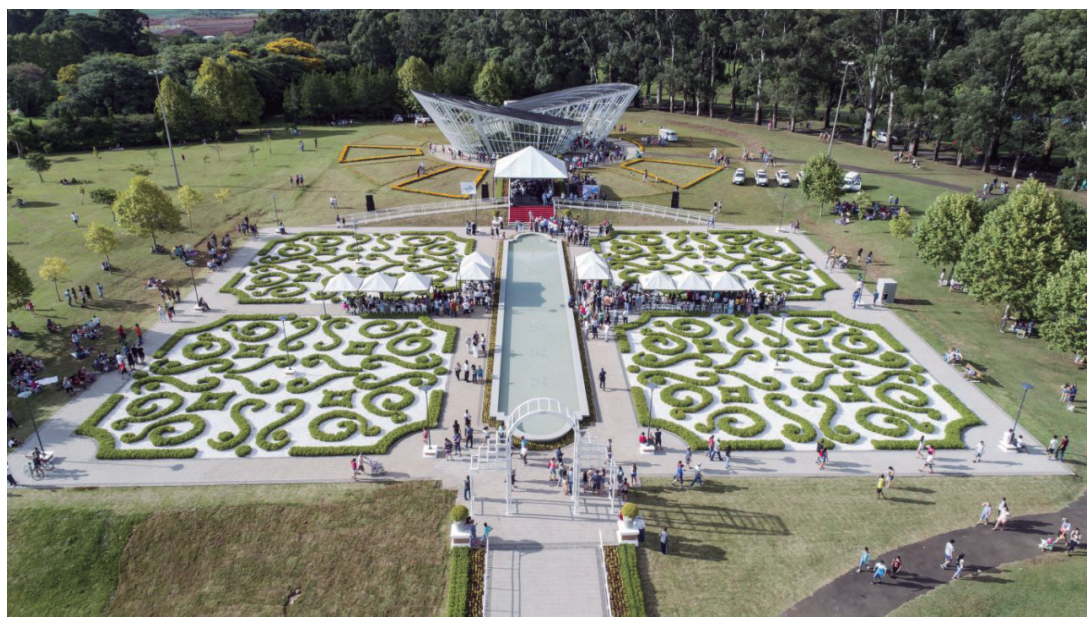

Fonte: Revista Visual (2018)

Recentemente, com a instalação do Shopping da Cidade dos Lagos próximo ao Parque, novos loteamentos de alto padrão foram disponibilizados para venda, inclusive em condomínios fechados. Essa área será um enclave numa região de moradias de classe média baixa e/ou de baixa renda que viram a infraestrutura transformar-se rapidamente com a instalação desse equipamento privado, o Shopping, como vias de circulação pavimentadas, galerias pluviais e de esgoto e iluminação, por exemplo. Serviços que para muitos deles só chegaram nos últimos dez anos, embora os bairros próximos, Primavera e Industrial, já sejam densamente povoados há pelo menos 40 anos.

Figura 10. Parque do Lago, Guarapuava, PR

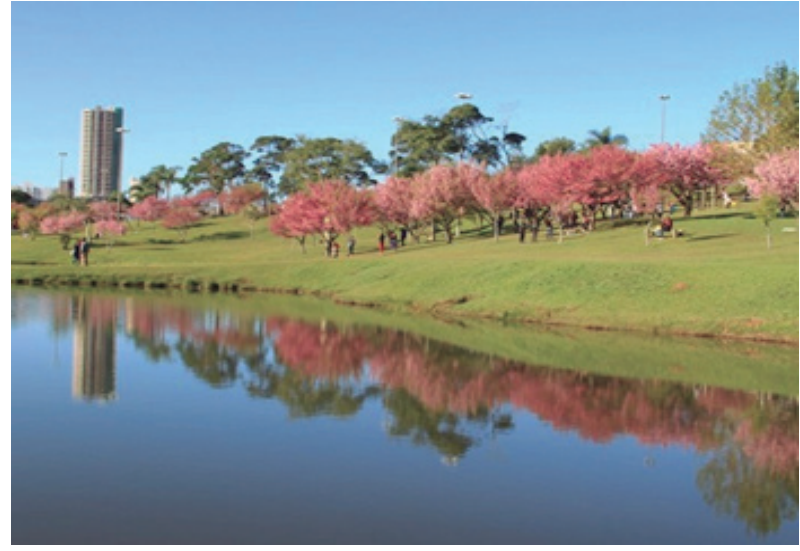

Fonte: http://g1.globo.com/pr/campos-gerais-sul/ noticia
Figura 11. Lagoa das Lágrimas, Guarapuava, PR.

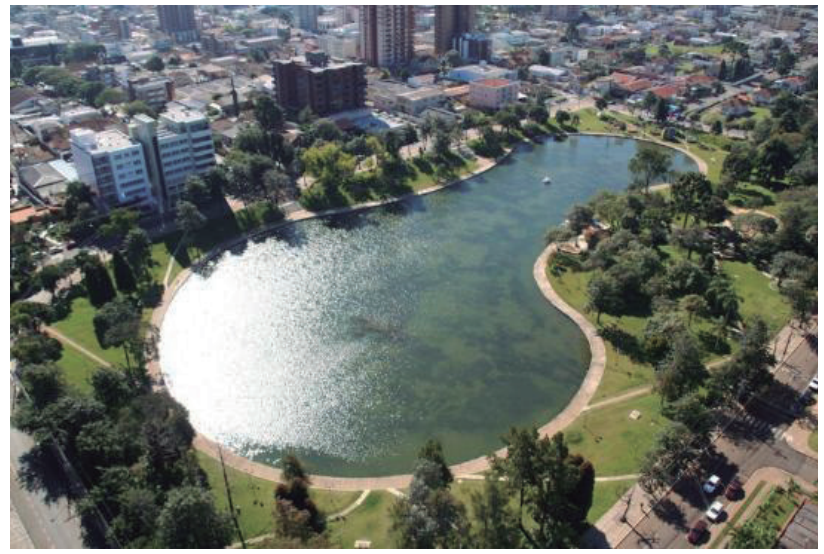

Fonte: www.tripadvisor.com.br

Outros espaços oferecem à população diferentes opções de lazer e entretenimento, como o já citado Parque do Lago (Fig. 10) e a Praça Eurípio Rauen (Fig. 11), conhecida popularmente como Lagoa das Lágrimas, ambas na área central. 
O Parque do Lago foi criado na década de 1990, em um fundo de vale tomado por vegetação, sem utilização pública e que estava sujeito a inundações frequentes. A área estava parcialmente ocupada por moradias precárias, muitas delas sem título de propriedade, e a revitalização do espaço implicou na expropriação e remoção dessas famílias. Em pouco tempo houve valorização do local, especulação imobiliária, e uma mudança no uso e na posse das propriedades ao entorno (Gomes, 2012).

Atualmente, é uma das áreas verdes mais democráticas da cidade, frequentado por pessoas de diferentes classes sociais, e nele são realizadas várias atividades esportivas e culturais. No entanto a Lagoa das Lágrimas, por exemplo, é uma das áreas mais valorizadas da cidade e considerada pelos alunos um local frequentado por pessoas de classe média alta, o que, segundo uma das jovens, impõe um certo constrangimento: "Na Lagoa só vai gente metida, são todos chique, mesmo assim eu vou lá as vezes. Mas prefiro ir no Lago" (aluna F19). Mais uma vez observa-se aqui certa segregação territorial como expressão da desigualdade social, já mencionada.

No âmbito da mediação, ao problematizar com eles a apropriação desses lugares, buscou-se discutir os interesses econômicos e políticos na revitalização urbana e como isso gera a melhoria de determinadas áreas, mas contraditoriamente, expropria determinados grupos sociais.

\section{B) Percepção dos moradores sobre os espaços de lazer em Guarapuava - Entrevistas}

Para essa atividade foram empregados dois textos para embasar a discussão e a preparação das entrevistas: Trabalho de campo pela rua XV de Novembro: Desvendando a sociabilidade juvenil em Guarapuava - PR (Ferreira \& Turra Neto, 2006) e Análise das políticas públicas de esportes e lazer de Guarapuava - PR (Miguel \& Starepravo, 2008).

Os jovens foram orientados a entrevistar pessoas do seu bairro. O roteiro foi construído coletivamente, com as seguintes questões: Locais que procuram frequentar para se divertir? Locais que não frequentam? Motivos? Como é a infraestrutura dos locais que frequentam? Como costumam se locomover para ir a esses locais? Depois de realizada a pesquisa e a leitura dos textos, cada grupo apresentou-se na turma para os colegas.

O destaque nos resultados das entrevistas foi a infraestrutura, localização desigual e a falta de segurança encontrados nos espaços de lazer na cidade, principalmente relacionada ao uso de drogas e à violência. Conforme a aluna F3: "A população precisa ter acesso ao lazer para se distrair nas horas livres. Os jovens hoje em dia pedem muito por um emprego, mas pedem também por espaços esportivos, de recreação e cultura. Os espaços da cidade muitas vezes não são frequentados devido à falta de segurança. Para podermos sair e desfrutar desses espaços nas horas livres precisamos sentir segurança. Mas ultimamente está difícil".

Muitos entrevistados indicaram medo da violência ao sair em espaços públicos, principalmente à noite. Assim, descreveram vários exemplos de assaltos e assédio. Descobriram com essa pesquisa que as pessoas acabam frequentando espaços privados para praticar esportes (principalmente academias), ou simplesmente não saem de casa. Por meio da mediação, problematizaram-se esses dados, sobretudo quanto à importância da atuação do cidadão na cobrança em investimento em segurança pública. 
Além da segurança, outro dado que apareceu na pesquisa foi sobre os projetos esportivos desenvolvidos pela prefeitura. Uma das jovens participa desta ação e informou aos colegas que os projetos "Ocorrem no Lago (Bairro Batel) e na praça da Ucrânia (Bairro Trianon). Eu ia no Trianon e não pagava nada. Tem no Pinheiros, mas lá precisa pagar. Esses projetos são para tirar as crianças das ruas" (aluna F16).

Essa política pública a qual a jovem se refere é o Projeto de Escolinhas, que disponibiliza escolas de futsal, futebol de campo, judô, tênis de mesa, natação entre outros em diferentes bairros na cidade. O projeto foi implantado em 2017, e tem tido uma repercussão positiva importante entre jovens, sobretudo porque tem implicado na revitalização das quadras de esporte nos bairros e criação de outras. Na pesquisa, puderam constatar que os locais públicos de lazer na área central de Guarapuava são mutifuncionais, voltados para diversas atividades, como esportes, manifestações culturais, entretenimento, lazer etc.

Na mediação, informações sobre outros projetos foram socializadas, como aqueles que acontecem no Parque das Araucárias com trilhas interpretativas, gincanas, palestras e Verão na Praça, que são atividades desenvolvidas nos parques e praças da cidade, assim como, as atividades que acontecem em datas comemorativas no Parque do Lago e na Lagoa das Lágrimas, a exemplo daquelas no Dia do Trabalhador, ou os circuitos de corridas de rua, entre outros. Uma jovem destacou que "por isso é importante aproveitarmos o que tem, para incentivá-los a fazerem mais. Não adianta eles oferecerem e ninguém ir" (aluna F19). Sobre isso, discutiu-se sobre a importância da demanda como propulsora das políticas públicas, assim como para proporcionar a continuidade dos programas de Estado e não só de governo, ou seja, cobrar para que descontinuidades não gerem desestímulos aos jovens.

\section{C) Para além da paisagem - Pesquisa de Campo}

A pesquisa de campo teve como objetivo identificar a qualidade dos equipamentos públicos e privados de lazer e a observação dos seus usos e funções (lazer, trabalho, consumo, etc). Para isso, o roteiro contou com cinco pontos de observação: 1. Parque do Lago; 2. Bairro Vila Bela e Planalto; 3. Lagoa das Lágrimas; 4. Parque das Araucárias; 5. Shopping Cidade dos Lagos.

Na mediação foram sugeridas algumas questões para orientar a observação da paisagem: Há pessoas circulando por esses locais? Estão sozinhas ou em grupos? É possível estabelecer uma característica? Qual é a infraestrutura que o local oferece? Qual o estado de conservação desse espaço? Qual a localização do equipamento em relação ao centro da cidade? Outras observações poderiam ser anotadas no diário de campo, sugerido como meio de registro das observações.

Os jovens interagiram durante toda atividade de campo (Figs. 12 e 13). Várias anotações foram feitas por eles, dentre as quais destacamos:

- As praças e parques da cidade estão em bom estado de conservação;

- Na área central da cidade existe uma maior concentração de espaços de lazer; 
- Nos locais mais carentes as pessoas se utilizam mais dos espaços públicos de lazer disponíveis no bairro. "Lá no bairro sempre tem gente no ginásio, é difícil conseguir horário para jogar. Mas o ginásio tinha que ter banheiro para ficar melhor" (aluna, F16);

- Os espaços privados de lazer são frequentados por pessoas que têm dinheiro para consumir, observado por uma das jovens: "Viu quanta gente chique aqui no Shopping, as lojas são muito caras. Nós vamos só tomar um sorvetinho" (aluna F16).

- Uma diversidade grande de pessoas circula pelos espaços centrais públicos de lazer mas não necessariamente interagem entre si. Contudo, acabam usufruindo do mesmo espaço para diferentes objetivos como a prática de esportes, a conversa entre amigos, ouvir música e passear com a família;

- Não são todos os bairros que possuem espaços de lazer públicos e/ou privados.

Figura 12. Participantes da pesquisa no Parque do Lago

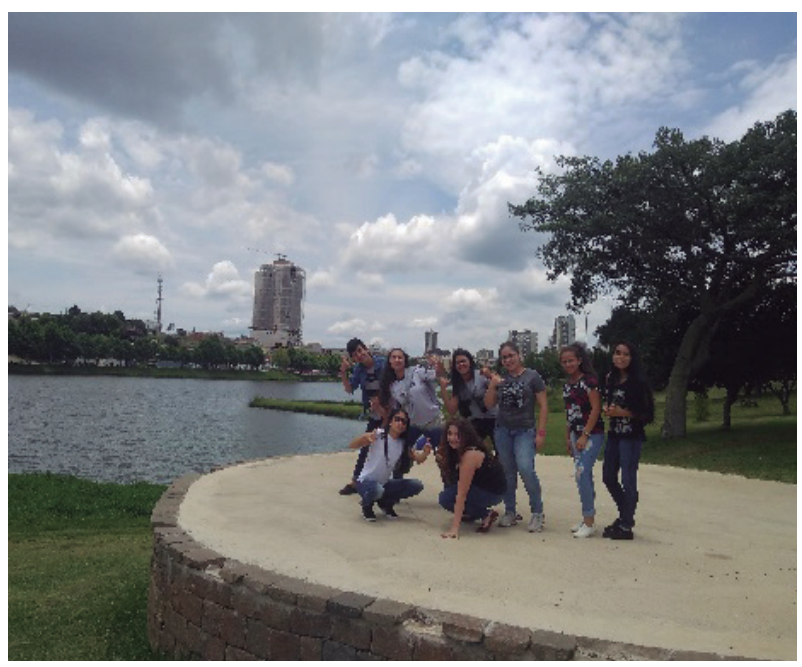

Figura 13. Participantes da pesquisa no Shopping Cidade dos Lagos

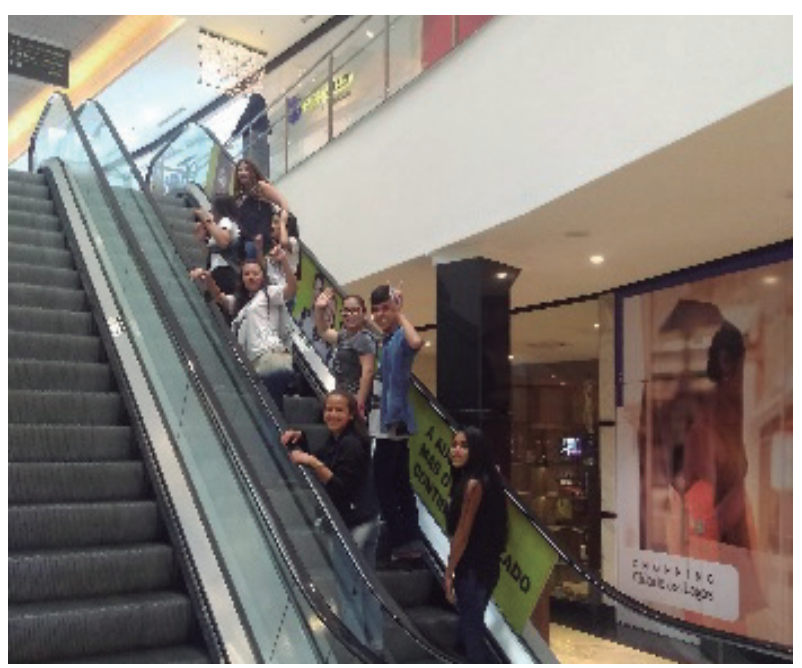

A partir das observações foi problematizado como as políticas públicas direcionadas ao lazer são necessárias, além da infraestrutura adequada, para incentivar o cidadão a integrar-se nos espaços públicos, sobretudo, se houver ações e espaços para diferentes faixas etárias. Além de projetos é necessário ainda que os espaços de lazer apresentem acessibilidade a todos, com sistema de transporte que favoreça o deslocamento com qualidade e baixo custo.

Outro fator observado foi certa limitação ao lazer para as famílias com menor poder aquisitivo. Essas moram longe do trabalho, dos serviços e dos equipamentos que a cidade oferece. Nos bairros o que se encontra, geralmente, são ginásio e academia da terceira idade que atendem apenas alguns segmentos da população, o que demonstra desigualdade no acesso ao lazer.

Foi possível observar no campo que a forma da cidade é marcada pelas práticas socioespaciais cotidianas, permeadas de contradições e conflitos, acontecimentos, etc. A fragmentação que orienta o processo de estruturação urbana, influencia no acesso aos espaços públicos (Loboda, 2008). Ou seja, as formas (física ou simbólica) de acesso interferem nas condições de uso e ocupação dos diferentes lugares da cidade. 


\section{Seminário de Socialização dos Trabalhos do Projeto Guarapuava Educadora: Jovens pensando a Cidade - Avaliação e Socialização}

A socialização dos trabalhos ocorreu por meio do Seminário de Socialização dos Trabalhos do Projeto Guarapuava Educadora: Jovens pensando a Cidade, no qual o Colégio Antônio Tupy Pinheiro participou. Os jovens da pesquisa apresentaram suas percepções sobre a cidade (após análise de imagens, entrevistas e pesquisa de campo) com a exposição da síntese de seus trabalhos, no formato de banners, com sugestões de melhorias para a cidade (Quadro 1).

Quadro 1: Observações e sugestões dos alunos na pesquisa de campo.

\begin{tabular}{|c|c|}
\hline Observações & Sugestões \\
\hline $\begin{array}{l}\text { - Espaços públicos de lazer nas regiões centrais } \\
\text { ou próximas ao centro da cidade têm melhores } \\
\text { infraestruturas em relação aos espaços mais afastados. } \\
\text { - Nos espaços públicos de lazer dificilmente } \\
\text { encontramos banheiros. } \\
\text { - Nos espaços privados de lazer a infraestrutura é bem } \\
\text { melhor, até mesmo referente à inclusão e acessibilidade. } \\
\text { - Muitas áreas de lazer são pouco utilizadas pelos } \\
\text { cidadãos devido ao medo da violência. } \\
\text { - Projetos desenvolvidos pela prefeitura nas áreas mais } \\
\text { centrais da cidade, como por exemplo, Verão na Praça e } \\
\text { as feiras no Parque do Lago aumentam a frequência de } \\
\text { pessoas nesses espaços. }\end{array}$ & $\begin{array}{l}\text { - Oferecer a mesma infraestrutura aos espaços de lazer } \\
\text { localizados nas áreas mais distantes do centro cidade, } \\
\text { como por exemplo, no Jardim das Américas que é } \\
\text { precário nesse quesito. } \\
\text { - Disponibilizar banheiros e torneiras com água nos } \\
\text { espaços públicos de lazer. } \\
\text { - Investir em segurança dos espaços de lazer. } \\
\text { - Desenvolver atividades com a população para } \\
\text { conscientização da preservação dos espaços públicos. } \\
\text { - Divulgar nas escolas as atividades de esporte e lazer } \\
\text { desenvolvidas pela prefeitura. } \\
\text { - Disponibilizar transporte com valor reduzido também } \\
\text { nos finais de semana para os jovens frequentarem as } \\
\text { atividades de lazer mais distantes de sua casa. }\end{array}$ \\
\hline
\end{tabular}

Durante o seminário, os jovens conseguiram expor suas concepções relacionadas aos temas trabalhados, se utilizando dos conteúdos e conceitos geográficos apreendidos, aprofundaram suas reflexões, inclusive sugerindo modificações para melhoria de seu bem-estar e da sociedade local.

Refletindo sobre as dimensões da cidade educadora, apresentada por Bernet (1997), verificou-se que, a cidade de Guarapuava ensina diretamente culturas, formas de vida, tradições, costumes e valores e, por isso mesmo, é importante que a população viva as ruas da cidade, ou seja, que circulem, brinquem, frequentem as ruas e os espaços públicos. Porém, há uma desigualdade de acesso e a necessidade de políticas públicas voltadas para a segurança, mas também para o entendimento da importância de apropriação dos lugares pela população como forma de lhes dar novos usos, fato que também promove uma mudança qualitativa do espaço.

Sobre a sequência didática, notou-se a grande aceitação, entusiasmo e satisfação de todos os alunos. Com destaque para alguns relatos deles: "Nesse tempo que fizemos todas as etapas foi uma experiência muito legal, nunca tivemos aulas dessa maneira de ter vontade de participar, ir nas aulas de campo, observar a cidade..." (aluna F2), e "(...) viemos realizando um trabalho que rendeu muito aprendizado e conseguimos conhecer mais da cidade e sobre os conceitos de mobilidade, lazer, segregação e o lugar que moramos" (aluno M8), e "Foi muito bom, por ser nossa experiência, com campo e prática, muito participativo, quero refazer novamente" (aluno M7). 
Ainda, na avaliação, relataram que ficaram nervosos ao falar para um número grande de pessoas que não conheciam, mas que "adoraram a experiência" de compartilhar seus trabalhos com outros estudantes e se sentiram valorizados com a presença dos representantes externos que vieram prestigiar o evento. Houve a participação dos demais professores da escola, da universidade, dos membros do Núcleo Regional de Educação e do Poder Público Municipal, inclusive acolhendo suas sugestões.

Um ponto negativo relatado refere-se à leitura dos textos, que lhes pareceu cansativo e demorado, embora tenha sido, segundo eles, de grande valia para sua aprendizagem. Percebeu-se então que o hábito da leitura não é frequente entre os jovens, sobretudo como forma de melhor compreender um fenômeno e processo. Imersos na cultura da imagem e na leitura de textos curtos e sintéticos, qualquer proposta que exija mais concentração e dedicação à leitura levanta resistência. Contudo, entende-se que o professor pode combinar atividades, diversificando-as, de modo a garantir também o espaço para dedicação à reflexão a partir de atividades de interpretação de textos. A atenção e a constância são elementos importantes à formação do pensamento crítico.

Da parte dos representantes institucionais, participantes do evento, também foi significativa a percepção dos professores e dos representantes do poder público sobre a importância em se ouvir os alunos e conhecer suas sugestões. Ficou claro que o potencial pedagógico está no processo de envolvimento dos alunos, seu protagonismo, valorização de suas experiências aliados à mediação do professor, cuja intencionalidade pedagógica é bem definida no processo didático de condução do processo.

\section{CONSIDERAÇÕES FINAIS}

A perspectiva da cidade educadora visa uma maior intensidade na relação ativa entre e com os sujeitos no/do espaço. Para que essa interação aconteça, é preciso que os sujeitos tenham consciência da concepção de mundo e de sociedade que se espera. Neste caso, acredita-se que o melhor seria aquele com princípios democráticos e de justiça social.

Na escola, a geografia escolar pode participar desse processo, na medida em que se constitui como uma instância formadora da cidadania. Criar condições para que o cotidiano seja problematizado em sala de aula, que os conhecimentos geográficos estejam a serviço para desvendá-lo é um caminho para que o professor possa contribuir com o jovem na percepção e entendimento do mundo.

Na pesquisa, percebeu-se que o conteúdo escolar relacionado ao cotidiano dos jovens foi muito atrativo, despertou seu interesse pelo conhecimento, e culminou em uma maior eficiência em relação à formação do pensamento conceitual. Isso foi possível, pois se buscou, no ensino da Geografia, proporcionar instrumentos para a formação de conceitos e, consequentemente, contribuir para o pensamento geográfico dos jovens. Instigá-los a ler as paisagens da cidade, desnaturalizar o espaço produzido, e aproximá-los desse espaço, foi importante para que houvesse a aprendizagem significativa. 
A SD realizada com os jovens sobre os espaços de lazer na cidade foi importante, pois o tema tem um importante papel na sua socialização. O lazer é o momento em que os jovens têm liberdade para escolher onde e com quem querem estar, livre dos olhos orientadores dos pais e professores. Também é no lazer que se amplia a possibilidade da manifestação da 'cultura juvenil', uma relativa oposição à cultura dominante dos mais velhos.

Em tempos de internet, das conexões online, a qual intensificou as possibilidades de comunicação (na escala mundo), também se verifica na pesquisa que, cada vez mais se reduzem as experiências offline, cujas implicações já podem ser vistas na dificuldade de construção de empatias, solução de conflitos e vínculos sociais em comunidade. A sensação de insegurança na cidade, intensificadas pela divulgação sistemática de violência urbana, gera mais reclusão. Não se trata de ignorar as mazelas sociais, mas de insistir na apreensão e compreensão do espaço geográfico de modo a mobilizar os jovens para lutar por direitos, dentre eles a cidade mais segura, apropriando-se dela.

Apropriar-se para que se possa "aprender da cidade" (Bernet, 1997), enquanto um agente informal de educação. Aprender cotidianamente, ao viver as ruas, os espaços públicos da cidade, conhecida como escola da vida. E, assim, enriquecer o conhecimento cultural e científico que por sua vez, ajudarão na defesa da cidadania.

Na pesquisa e nas atividades pedagógicas, os jovens perceberam que possuem um saber experiencial, que precisa ser refletido para torná-los conscientes e são os conhecimentos geográficos que lhes permitiram compreender melhor essa trama, daí também o significado que os conteúdos e conceitos têm na formação do pensamento geográfico.

Ao valorizar o cotidiano dos jovens, eles se sentiram reconhecidos, o que promoveu maior motivação para as atividades propostas. A cidade oferece um conjunto de possibilidades de abordagem dos conteúdos geográficos e, para além de compreender os processos, pensar sobre a cidade local foi importante para o protagonismo dos jovens não só no reconhecimento dos problemas, mas também na construção de soluções.

\section{REFERÊNCIAS}

Bernet, Jaume Trilla (1997). Ciudades Educadoras: Bases Conceptuales. In M.A.S. Zainko (Org.) Cidades Educadoras. (pp. 13-34). Curitiba: Ed. UFPR.

Brarda, Analía, \& Ríos, Guilherme (2004). Argumentos e estratégias para a construção da cidade educadora. In M. Gadotti, P.R., \& A. Cabezudo (Orgs.) Cidade educadora, princípios e experiências. (pp.15-44). São Paulo: Cortez.

Brasil. Ministério da Saúde. (2010). Índice Gini da renda domiciliar. Recuperado de http://tabnet.datasus. gov.br/cgi/ibge/censo/cnv/ginipr.def

Carrano, Paulo César Rodrigues (2003). Juventudes e cidades educadoras. Petrópolis: Vozes.

Carrano, Paulo César Rodrigues (2011). Jovens, escolas e cidades: Desafios à autonomia e à convivência. Revista Teias, 12(26), 7-22.

Cassab, Clarice, Mendes, Juliana, \& Thimóteo, Nazareno. (2011). Perder-se Também é Caminho. Dimensão espacial da Juventude. Revista Libertas, 11(2), 181127. DOI: https://doi.org/10.34019/1980-8518.2011. v11.18127 
Cavalcanti, Lana Souza (2005). Cotidiano, Mediação Pedagógica e Formação de Conceitos: Uma contribuição de Vygotsky ao ensino de geografia. Cad. Cedes, 25(66),185-207. Recuperado de http://www. cedes.unicamp.br

Dayrell, Juarez (2005). Um olhar sobre a juventude. In Juarez Dayrel. A música entra em cena: o rap e o funk na socialização da juventude. (pp. 21-44). Belo Horizonte: Ed. UFMG.

EducartGEO (2019). Relatório do Grupo de Pesquisa e Extensão Educação Geográfica e Cartográfica para Escolares. In Marquiana de Freitas Vilas Boas Gomes (Coord). Relatório do Projeto de Extensão Guarapuava educadora: juventude educando-se na/com a cidade. Guarapuava: UNICENTRO.

Ferreira, Sandra Cristina, \& Turra Neto, Nécio (2006). Trabalho de campo pela rua XV de Novembro: Desvendando a sociabilidade juvenil em Guarapuava - PR Revista Formação, 13, 77-105.

Filmus. Daniel Fernando (1997). Escuela y Ciudade Educadora: Uma relación a profundizar. In M.A.S. Zainko (Org.) Cidades Educadoras. (pp. 75-89). Curitiba: Ed. UFPR.

Gadotti, Moacir (2006). A Escola na Cidade que Educa. Cadernos Cenpec, 1(1), 133-139. Recuperado de http://cadernos.cenpec.org.br/cadernos/index.php/cadernos/article/view/160

Gomes, Marquiana de Freitas Vilas Boas (2012). Trajetória Ambiental de Guarapuava: leituras da paisagem. Guarapuava: Ed. UNICENTRO.

Instituto Brasileiro de Geografia e Estatística (1991). IBGE Cidades. Recuperado de https://cidades.ibge. gov.br/brasil/pr/guarapuava/historico

Instituto Brasileiro de Geografia e Estatística (2000). Contagem da população. IBGE Cidades. Recuperado de https://sidra.ibge.gov.br/home/ipca15/brasil

Instituto Brasileiro de Geografia e Estatística (2010). IBGE Cidades. Recuperado de https://cidades.ibge. gov.br/brasil/pr/guarapuava/panorama

Instituto Paranaense de Desenvolvimento Econômico e Social (1991). Base de dados do Estado (BEDweb). Recuperado de http://www.ipardes.gov.br/imp/index.php

Instituto Paranaense de Desenvolvimento Econômico e Social. (2000). Caderno Estatístico do Município de Guarapuava. Recuperado de http://www.educadores.diaadia.pr.gov.br/arquivos/File/cadernos_ municipios/guarapuava.pdf

Instituto Paranaense de Desenvolvimento Econômico e Social (2010). Caderno Estatístico do Município de Guarapuava. Recuperado de http://www.educadores.diaadia.pr.gov.br/arquivos/File/cadernos_ municipios/guarapuava2012.pdf

Instituto Paranaense de Desenvolvimento Econômico e Social (2018). Caderno Estatístico do Município de Guarapuava. Recuperado de http://www.ipardes.gov.br/cadernos/MontaCadPdf1. php?Municipio $=85000$

Loboda, Carlos Roberto (2008). Práticas Sócioespaciais e Espaços Públicos em Guarapuava - Pr. (Tese de Doutorado). Faculdade de Ciências e Tecnologia - FCT, Universidade Estadual Paulista, São Paulo, SP, Brasil.

Menandro, Maria Cristina Smith, Trindade, Zeide Araújo, Almeida, Angela Maria de Oliveira et al. (2003). Representações sociais da adolescência/juventude a partir de textos jornalísticos (1968-1974 e 1996-2002). Arquivos Brasileiros de Psicologia, 55(1), 42-55.

Miguel, Robson Geovane, \& Starepravo, Fernando (2008). Análise das Políticas Públicas de Esportes e Lazer de Guarapuava - PR. Anais do Encontro da Alesde, Curitiba, Brasil, 1.

Programa das Nações Unidas para o Desenvolvimento (2010). IDH Municípios 2010. Recuperado de https:/ / www.br.undp.org/content/brazil/pt/home/idh0/rankings/idhm-municipios-2010.html

Serpa, Angelo (2007). O espaço público na cidade contemporânea. São Paulo: Contexto.

Thiollent, Michel (2004). Metodologia da pesquisa-ação. (13a. ed.) São Paulo: Cortez. 
Turra Neto, Nécio (2008). Múltiplas Trajetórias Juvenis em Guarapuava: territórios e redes de sociabilidade (Tese de Doutorado). Universidade Estadual Paulista - UNESP, Presidente Prudente, SP, Brasil.

Vygotsky, Lev Semenovitch (2001). A construção do pensamento e da linguagem. São Paulo: Martins Fontes.

Data de submissão: 14/maio/2019

Data de aceite: 20/jun./2020 